(c) Elsevier Scientific Publishing Company, Amsterdam - Printed in The Netherlands

\title{
GEOCHEMICAL ASSOCIATIONS AND GRAIN-SIZE PARTITIONING OF HEAVY METALS IN LACUSTRINE SEDIMENTS
}

\author{
LORRAINE H. FILIPEK and ROBERT M. OWEN \\ Department of Atmospheric and Oceanic Science, The University of Michigan, Ann Arbor \\ MI 48109 (U.S.A.)
}

(Received May 9, 1978; revised and accepted December 13, 1978)

\begin{abstract}
Filipek, L.H. and Owen, R.M., 1979. Geochemical associations and grain-size partitioning of heavy metals in lacustrine sediments. Chem. Geol., 26: 105-117.

A sequential extraction scheme is utilized to determine the geochemical fractionation of $\mathrm{Fe}, \mathrm{Mn}, \mathrm{Cr}, \mathrm{Cu}$ and $\mathrm{Zn}$ in different grain size classes for sediment samples collected from within and around Little Traverse Bay, Lake Michigan. The partitioning of $\mathrm{Fe}, \mathrm{Cr}$ and $\mathrm{Cu}$ in both sediment and presently-eroding coastal bluff samples are similar. Also, the concentrations of these metals in fine-grained particles are not proportional to the increased surface area of these grains compared with larger grain sizes. Both of these results indicate that these metals have undergone little authigenic change since entering the lacustrine environment. However, sediment $\mathrm{Zn}$ concentrations are significantly higher than in coastal bluff samples, and also have a different geochemical fractionation. This result is attributed to the precipitation of $\mathrm{Zn}$ in authigenic phases. In general, Mn shows relatively little mobility in the bay's oxidizing environment, except in areas where Mn nodules are forming.
\end{abstract}

\section{INTRODUCTION}

There is at present much interest in the distribution and fate of heavy metals in lacustrine sediments. This is particularly true of the Great Lakes, which are the world's largest freshwater bodies. These lakes border on several highly industrialized cities, which pollute the lakes both by direct dumping of wastes and by atmospheric inputs. To protect these and other lakes from possible irreversible damage, it is necessary to understand the chemical and biological behavior of heavy metals in both pristine and polluted aquatic systems. An important aspect of this understanding is the determination of the actual geochemical associations of the metals in sediments, as well as an assessment of the relative mobility of each of these metal states.

Until recently, the geochemical associations of heavy metals were determined indirectly by statistical inference; however, direct extraction methods are now available. The most complete chemical fractionation method to date was that developed by Engler et al. (1974) and subsequently modified by 
Gupta and Chen (1975) for use in marine sediments. This method consists of a sequential chemical extraction scheme which chemically separates the carbonate and amorphous Mn oxide, oxidizable (organic and sulfide), reducible (hydrous oxide), and lithogenous, or crystalline, fractions.

This extraction scheme determines the actual states of the metals in the sediments, but does not necessarily indicate whether the geochemical associations are primary (i.e., formed before entering the lacustrine environment), or are due to authigenesis within the present aquatic system. This information is important in understanding the mobility of the metals.

Two complementary methods are used in this study to investigate the extent of authigenesis in a pristine lacustrine environment. The first method involves the influence of grain size on metal distributions. This method is based on the reasoning that the grain-size-metal-concentration relationship in a given phase depends upon the circumstances of formation of that phase. For example, grain size is an important factor in considering the concentration of metals in detrital particles because particles of different mineralogies are segregated by size during transport and deposition. On the other hand, concentrations of authigenically-derived metal phases are surface-area-related (and thus also size-related) because these precipitate onto pre-existing particles The second method involves a direct comparison of metal concentrations in the various chemical extracts of sediments with the metal concentrations in the same extracts from samples of neighboring coastal bluffs and outcrops which are presently eroding. This comparison yields information on the influence of the various detrital components on the transport of the metals.

The specific objectives of our study are: (1) to determine the distribution of the heavy metals $\mathrm{Fe}, \mathrm{Cr}, \mathrm{Cu}, \mathrm{Zn}$ and $\mathrm{Mn}$ among the various geochemical fractions of surficial sediments in a relatively unpolluted lacustrine environment; and (2) to assess the relative importance of authigenic processes vs. detrital input in arriving at this distribution.

\section{REGIONAL SETTING}

The area selected for this study is Little Traverse Bay, a pristine bay located in NE Lake Michigan (Fig.1). A sandy ridge which extends north from the SW bay floor and terminates in a restricted channel near the northern coast separates the bay from Lake Michigan. The southern shoreline of the bay is formed by a limestone cuesta of Middle Devonian age (Moore, 1961). Outcrops along this shore are actively eroding and comprise the main source of carbonate sediments in the bay. The north and east shores of the bay are composed of quartz sand beaches with no bedrock outcrops. Occasional bluffs of red glacial till composed chiefly of carbonate minerals, quartz and feldspar are exposed inland of these beaches (Rea and Pigula, 1977). The adjacent land area consists mainly of moraines and till plains which show little evidence of erosion and are poorly drained. Fluvial input to the bay is minor; thus the eroding sandy beaches of the north shore and their adjacent unconsolidated 


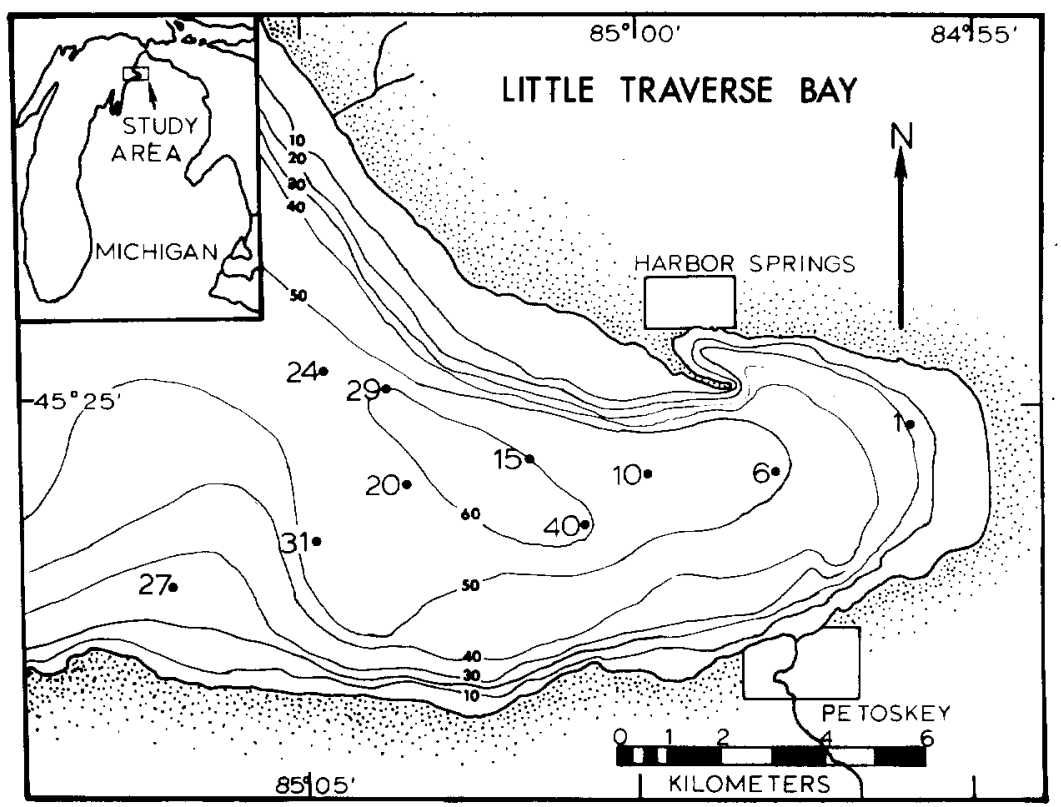

Fig. 1. Bathymetry of Little Traverse Bay, Lake Michigan, and sampling locations for sediments and coastal bluffs.

deposits of glacial till and outwash form the bulk of the detritus entering the bay (Moore, 1961; Rea and Pigula, 1977).

The general circulation pattern in the bay consists of eastward-flowing longshore currents along both the north and south shores, with a westward return flow at depth along the central trough (Pigula et al., 1977). This circulation is driven by the predominantly westerly winds over northern Lake Michigan.

The water quality of Little Traverse Bay is high due to the limited industry around the bay and low population density. These conditions permit the influence of mineralogy, grain size and organic matter on heavy-metal partitioning to be investigated without bias due to anthropogenic inputs.

\section{METHODS}

A total of 49 surficial sediment samples were collected from Little Traverse Bay during a cruise of the R.V. "Laurentian" in the summer of 1976. The samples were recovered with a Ponar ${ }^{\circledR}$ grab sampler and were immediately placed in polyethylene bags and refrigerated pending subsequent analysis.

In a preliminary analysis, separate portions of each sample were analyzed for organic and carbonate-C content (Using a Leco ${ }^{\circledR}$ carbon analyser) and grain-size distribution. Based on these results, ten of the original samples which represented the broadest possible range of those sediment properties determined in the preliminary analysis (Fig. 1, Table I) were selected for a detailed analysis of heavy-metal geochemistry. Coastal bluff and outcrop samples were collected by hand in the spring of 1977 . 
TABLE I

Sediment characteristics of Little Traverse Bay, Lake Michigan * ${ }^{1}$

\begin{tabular}{|c|c|c|c|c|c|c|c|c|c|c|}
\hline Station No.*2 & 1 & 6 & 10 & 15 & 20 & 24 & 27 & 29 & 31 & 40 \\
\hline Wa & 10 & 50 & 58 & 60 & 59 & $\mathbf{5 7}$ & 22 & 60 & 55 & 60 \\
\hline (wto & 86 & 6 & 10 & 6 & 1 & 78 & $>99$ & 63 & 8 & 5 \\
\hline Silt $(3.9-63 \mu \mathrm{m})(w t . \%)$ & 11 & 56 & 69 & 64 & 65 & 16 & $\mathbf{0}$ & 20 & 53 & 67 \\
\hline$<3.9 \mu \mathrm{m})(w t . \%)$ & 3 & 38 & 21 & 30 & 24 & 6 & $\mathbf{0}$ & 17 & 39 & 28 \\
\hline Organic C (wt.\%) & 1.18 & 4.41 & 3.60 & 4.90 & 3.54 & 0.22 & 0.06 & 0.59 & 3.89 & 4.95 \\
\hline Carbonate-C (wt.\%) & $\mathbf{3 . 3 3}$ & 4.50 & 4.27 & $\mathbf{3 . 1 3}$ & 2.77 & 0.48 & 0.26 & 2.57 & 2.23 & 3.16 \\
\hline
\end{tabular}

*' Grain size from Rea and Pigula (1977).

$*^{2}$ Station numbers correspond to Fig. 1.

The grain-size separation was achieved by wet-sieving a well-mixed subsample of sediment $(\sim 20 \mathrm{~g})$ in a glove bag under a $\mathrm{N}_{2}$ atmosphere. Sand $(>63 \mu \mathrm{m})$ was collected on a sieve, transferred to a closed container, and placed in a sonic bath for approximately $15 \mathrm{~min}$. to break up any aggregates. This fraction was then re-sieved and analyzed separately. Clay and silt were separated by differential settling in deaerated distilled water, with the claysilt boundary taken as $3.9 \mu \mathrm{m}$.

The analysis of heavy metals within different geochemical fractions of each major size group was done according to a sequential extraction scheme based on procedures developed by Chester and Hughes (1967), Nissenbaum (1972), and Gupta and Chen (1975) (Fig. 2). This scheme is designed to isolate heavy metals in the following geochemical fractions: (1) carbonates and exchangeable metals; (2) organics, sulfides and Mn oxides; (3) Fe oxides and hydroxides; and (4) lattice-held metals in crystalline mineral grains. The details of this analytical scheme have been discussed in other papers (Gupta and Chen, 1975; Filipek and Owen, 1978) and only a flow chart (Fig. 2) is shown here. The concentration of the heavy metals $\mathrm{Cr}, \mathrm{Cu}, \mathrm{Fe}, \mathrm{Mn}$ and $\mathrm{Zn}$ was determined in each fraction by atomic absorption spectrophotometry.

It should be noted that $\mathrm{Mn}$ nodules from station 24 were found to be removed in the organic-sulfide step. Therefore, a weak $\mathrm{NH}_{2} \mathrm{OH}-\mathrm{HCl}$ extraction designed to remove the nodules (Chao, 1972; Filipek and Owen, 1978) was inserted before the organic-sulfide step for this one station. Very low concentrations of metals other than Mn were extracted by the additional step (Fe, 220 ppm; Zn, 2 ppm; Cr, Cu, <1 ppm).

\section{RESULTS AND DISCUSSION}

The general characteristics of the sediments are shown in Table I. Grainsize distributions for individual samples generally reflect bottom topography. Silt is the dominant grain-size mode in the deeper stations, whereas the shallower stations contain mostly sand. However, sandy sediments also are found along the western boundary of the bay in the channel, probably as a result of faster bottom currents caused by constricted flow. The dominant mineral- 


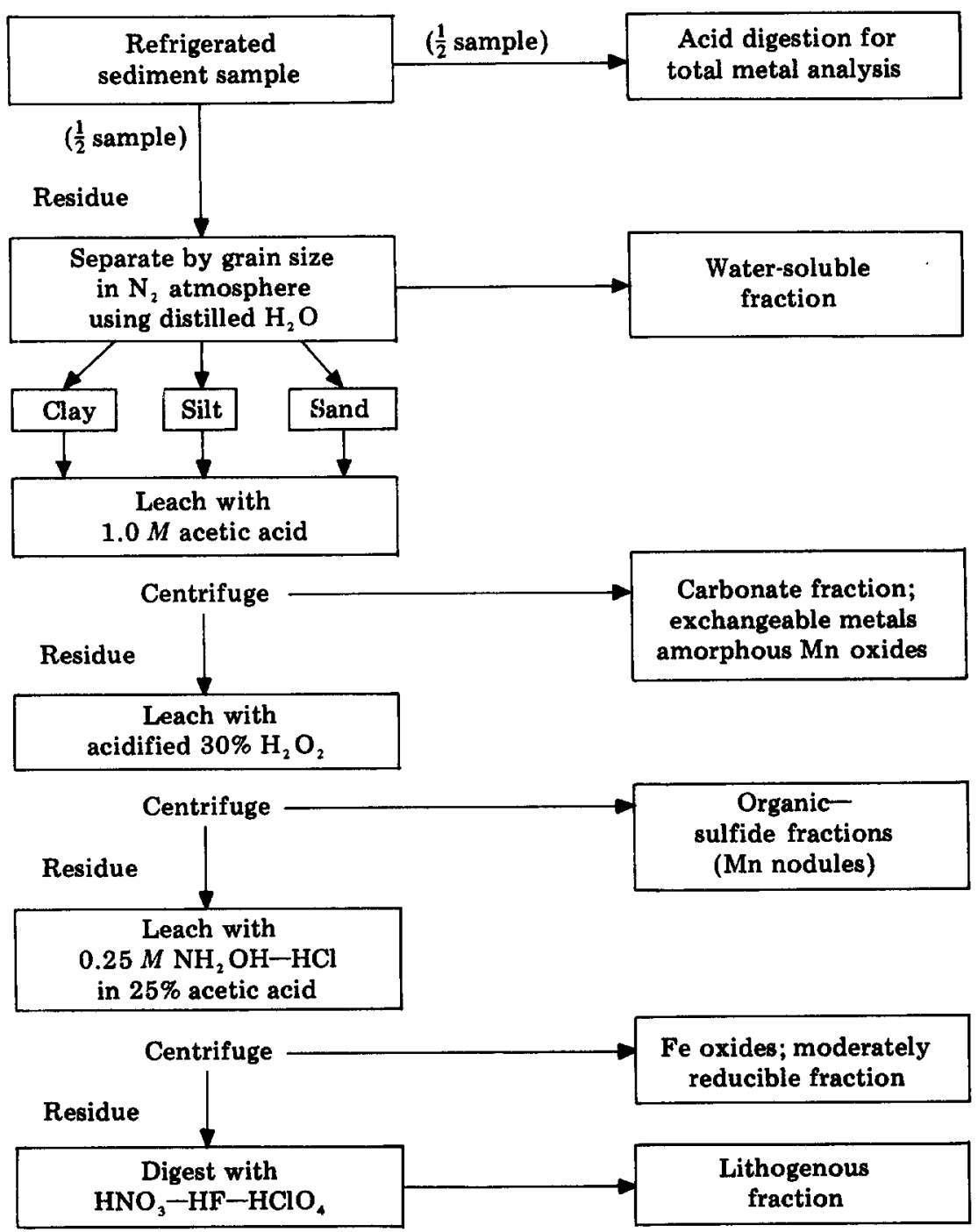

Fig. 2. Flow chart of physical and chemical separation of sediment samples.

ogical components of the sediment are quartz, carbonates, clay minerals (mostly illite and chlorite), and feldspars (Rea and Pigula, 1977). Rea and Pigula (1977) have shown that the carbonate-C content of the sediments decreases from east to west in the deeper portion of the bay, with the main input being the carbonate outcrops along the southern shores. Organic $\mathrm{C}$ increases with increasing silt and clay content (Table I).

Total heavy-metal concentrations (Table II) are reported as: (1) the total as determined by $\mathrm{HF}-\mathrm{HNO}_{3}-\mathrm{HClO}_{4}$ extraction; and (2) the sum of the in- 
TABLE II

Total heavy metals (in $\mu \mathrm{g} / \mathrm{g}$ dry sediment) for stations in Little Traverse Bay, Lake Michigan

\begin{tabular}{|c|c|c|c|c|c|c|c|c|c|c|c|}
\hline \multicolumn{2}{|c|}{ Station No. } & \multirow{2}{*}{ 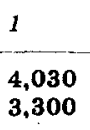 } & \multirow{2}{*}{$\begin{array}{l}6 \\
17,500 \\
17,100\end{array}$} & \multirow{2}{*}{$\begin{array}{l}10 \\
17,600 \\
18,200\end{array}$} & \multirow{2}{*}{$\begin{array}{l}15 \\
22,300 \\
23,500\end{array}$} & \multirow{2}{*}{$\begin{array}{l}20 \\
17,600 \\
19,700\end{array}$} & \multirow{2}{*}{$\begin{array}{l}24 \\
\mathbf{5 , 9 5 0} \\
\mathbf{4 , 6 8 0}\end{array}$} & \multirow{2}{*}{$\begin{array}{l}27 \\
\mathbf{2 , 2 6 0} \\
\mathbf{2 , 1 4 0}\end{array}$} & \multirow{2}{*}{$\begin{array}{l}29 *^{1} \\
9,510 \\
7,670\end{array}$} & \multirow{2}{*}{$\begin{array}{l}31 \\
18,500 \\
21,800\end{array}$} & \multirow{2}{*}{$\begin{array}{l}40 \\
25,500 \\
\mathbf{2 5 , 1 0 0}\end{array}$} \\
\hline $\mathrm{Fe}$ & $\begin{array}{l}\text { total } \\
\text { sum }\end{array}$ & & & & & & & & & & \\
\hline $\mathrm{Cr}$ & $\begin{array}{l}\text { total } \\
\text { sum }\end{array}$ & $\begin{array}{l}10.9 \\
11.9\end{array}$ & $\begin{array}{l}43 \\
47\end{array}$ & $\begin{array}{l}62 \\
62\end{array}$ & $\begin{array}{c}72 \\
<68^{* 2}\end{array}$ & $\begin{array}{r}57 \\
<69\end{array}$ & $\begin{array}{r}15 \\
<15\end{array}$ & $\begin{array}{l}4.9 \\
6.2\end{array}$ & $\begin{array}{l}30 \\
28\end{array}$ & $\begin{array}{l}56 \\
67\end{array}$ & $\begin{array}{l}50 \\
59\end{array}$ \\
\hline $\mathrm{Cu}$ & $\begin{array}{l}\text { total } \\
\text { sum }\end{array}$ & $\begin{array}{l}6.1 \\
5.8\end{array}$ & $\begin{array}{l}36.9 \\
36.6\end{array}$ & $\begin{array}{l}23.2 \\
23.9\end{array}$ & $\begin{array}{l}38.5 \\
32.5\end{array}$ & $\begin{array}{l}22.8 \\
27.5\end{array}$ & $\begin{array}{l}6.7 \\
6.9\end{array}$ & $\begin{array}{r}1.4 \\
<2.1\end{array}$ & $\begin{array}{l}22.5 \\
21.2\end{array}$ & $\begin{array}{l}61 \\
49\end{array}$ & $\begin{array}{l}54 \\
70\end{array}$ \\
\hline $\mathrm{Zn}$ & $\begin{array}{l}\text { total } \\
\text { sum }\end{array}$ & $\begin{array}{l}28.5 \\
28.9\end{array}$ & $\begin{array}{l}142 \\
145\end{array}$ & $\begin{array}{l}63 \\
70\end{array}$ & $\begin{array}{l}133 \\
160\end{array}$ & $\begin{array}{l}44 \\
76\end{array}$ & $\begin{array}{l}54 \\
54\end{array}$ & $\begin{array}{l}7.0 \\
8.2\end{array}$ & $\begin{array}{l}80 \\
41\end{array}$ & $\begin{array}{l}136 \\
125\end{array}$ & $\begin{array}{l}131 \\
167\end{array}$ \\
\hline $\mathbf{M n}$ & $\begin{array}{l}\text { total } \\
\text { sum }\end{array}$ & $\begin{array}{l}89 \\
75\end{array}$ & $\begin{array}{l}\mathbf{5 5 4} \\
\mathbf{5 5 8}\end{array}$ & $\begin{array}{l}448 \\
415\end{array}$ & $\begin{array}{l}651 \\
607\end{array}$ & $\begin{array}{l}285 \\
304\end{array}$ & $\begin{array}{l}2,300 \\
2,040\end{array}$ & $\begin{array}{l}36 \\
35\end{array}$ & $\begin{array}{l}174 \\
120\end{array}$ & $\begin{array}{l}327 \\
373\end{array}$ & $\begin{array}{l}567 \\
577\end{array}$ \\
\hline
\end{tabular}

The first value for each metal is from a single total extraction; the second value is the total as determined by the sum of all partial extractions.

*1 Sum values for station 29 are minimum values because some sample was lost during "lithogenous" extraction.

$*^{2}$ In some of the partial extractions, the concentration was below the detection limit. Therefore, the detection limit itself was used as a maximum value for that fraction.

dividual partial extractions. In most cases, these two numbers agreed to within $\pm 10 \%$. The results for individual fractions are discussed below.

\section{Lithogenous fraction}

The concentration of heavy metals in the crystalline, or lithogenous, fraction of coastal sediments is controlled almost exclusively by the mineralogy of the land-derived detrital fragments. Absolute concentrations of metals within this fraction are not affected by anthropogenic inputs (cf. Gibbs, 1973, 1977) and, further, any observed correlations between these concentrations and grain size are attributed to the fact that certain mineral groups are predominant in different grain-size classes (Folk, 1974; Sly and Thomas, 1974; Rea and Pigula, 1977).

The results of the present study indicate that at most stations approximately half of the total Fe and $\mathrm{Cr}$ are located in the lithogenous fraction (Table III). This fraction contains relatively smaller and more variable percentages of $\mathrm{Zn}$ and $\mathrm{Cu}(11-45 \%)$. The percentage of total $\mathrm{Mn}$ is also variable, accounting for $22-46 \%$ of the metal. Grain size has little influence on the relative amount of a given metal in the lithogenous fraction for most metals (Table III). However, the actual concentrations of metals in this fraction are dependent on the grain size of the sediment, with concentrations increasing as grain size decreases. At individual stations, the concentration increase from the sand to clay fraction ranges from 3- to 14-fold. This increase primarily represents the changing mineral composition with grain size. In these sediments, clay minerals, which have a high metal content, dominate the smaller grain sizes, whereas quartz and feldspars dominate the sand fraction (Pigula et al., 1977). 
Concentration ranges of heavy metals (in $\mu \mathrm{g} / \mathrm{g}$ dry sediment) in the sand, silt, and clay size fractions of sediments from Little Traverse Bay, Lake Michigan

\begin{tabular}{|c|c|c|c|c|c|c|c|c|c|c|}
\hline & \multicolumn{2}{|l|}{$\mathrm{Fe}$} & \multicolumn{2}{|l|}{$\mathrm{Cr}$} & \multicolumn{2}{|l|}{$\mathrm{Cu}$} & \multicolumn{2}{|l|}{$\mathrm{Zn}_{\mathbf{n}}$} & \multicolumn{2}{|l|}{ Mn* } \\
\hline & mean & SD & mean & SD & mean & SD & mean & SD & mean & SD \\
\hline \multicolumn{11}{|c|}{ Lithogenous: } \\
\hline sand & 1,320 & 222 & 5.6 & 3.3 & 2.8 & 3.6 & 4.3 & 3.8 & 21 & 7 \\
\hline silt & $\mathbf{9 , 5 8 0}$ & 2,350 & 32.5 & 8.5 & 10.2 & 7.6 & 27.2 & 8.4 & 88 & 27 \\
\hline clay & 15,100 & 5,570 & 59.5 & 16.5 & 16.5 & 6.6 & 38.8 & 13.6 & 124 & 40 \\
\hline \multicolumn{11}{|c|}{ Carbonate-exchangeable: } \\
\hline sand & 118 & 98 & 2.4 & 2.4 & 2.9 & & 8.4 & 10.1 & 22 & 24 \\
\hline silt & 513 & 319 & 4.0 & 1.2 & 6.5 & 2.0 & 32.2 & 18.7 & 205 & 69 \\
\hline clay & 1,040 & 782 & 5.0 & 1.4 & 24.0 & $\mathbf{3 . 3}$ & 90.8 & 46.6 & 198 & 116 \\
\hline \multicolumn{11}{|c|}{ Organic-sulfide: } \\
\hline sand & 1,530 & 1,450 & 4.5 & 4.3 & 2.9 & 3.1 & 7.2 & 5.8 & 8.6 & 7.4 \\
\hline silt & 2,880 & 393 & 7.6 & 4.6 & 15.9 & 5.4 & 20.9 & 10.6 & 106 & 83 \\
\hline clay & 8,570 & 1,990 & 23.5 & 6.4 & 32.5 & 5.3 & 80.5 & 19.0 & 95 & 37 \\
\hline \multicolumn{11}{|c|}{ Moderately reducible: } \\
\hline sand & 381 & 279 & 2.8 & 2.5 & 1.8 & 2.4 & 1.8 & 1.0 & 4.6 & 2.8 \\
\hline silt & 4,190 & 3,120 & 6.8 & 4.3 & 9.4 & 3.8 & 22.8 & 13.9 & 44 & 40 \\
\hline clay & 7,960 & $\mathbf{3 , 1 9 0}$ & 12.5 & 3.7 & 17.5 & 3.7 & 29.8 & 12.6 & 45 & 19 \\
\hline
\end{tabular}

$\mathrm{SD}=$ standard deviation.

*Does not include Mn nodules from station 24. (Nodules at that station have a Mn concentration of $1,860 \mu \mathrm{g} / \mathrm{g}$ sediment.)

\section{Grain-size dependence in the non-lithogenous fractions}

The partitioning of metals among the non-lithogenous fractions does not vary significantly with grain size. However, the actual concentrations increase by 2 - to 20 -fold from the sand to the clay fraction (Table III). In comparison, the surface area increases by a factor of at least $10^{5}$ between these size fractions, i.e. orders of magnitude larger than the change in metal concentrations. Because authigenic processes are generally considered surface-area-dependent, the small increase from sand to clay fraction in the metal concentrations suggests that the metals are primarily of detrital origin. It is important to note that this result could be biased if grain-size separations were incomplete or the sands included aggregates or porous cinders from ships. For example, if $2 \%$ by relative weight of clay remained in the sand fraction as aggregates and there were, in fact, a $10^{5}$ difference in surficial metal concentration between the clay and sand, the apparent difference would be reduced to 5,000-fold. However, even this difference is much greater than that observed. If the nonlithogenous metals are mainly of detrital origin, then the observed changes of concentration with grain size could be due to the different types of aeolian weathering occurring in sands and soils.

In the following discussion of the non-lithogenous fractions, the heavy-metal concentrations in each fraction are expressed as a percentage of the total nonlithogenous (N-L) metal, rather than of total metal because it is generally 
assumed that the lithogenous fraction is unavailable for further chemical reaction in the sediment. Thus, subtraction of the lithogenous fraction from the total yields the concentration of metals available to the environment (Gibbs, 1977).

\section{Carbonate and exchangeable fraction}

Heavy metals in the carbonate fraction of sediments may be either detrital or authigenic because many metals have carbonate species which are stable at natural $\mathrm{pH}$ and Eh conditions (Stumm and Morgan, 1970). However, metals in exchangeable positions are generally authigenic. Heavy metals in both of these phases are relatively mobile and are readily available for biological uptake, a process facilitated by the lowered $\mathrm{pH}$ of the digestive systems of many bottom-dwelling organisms (Copeland and Ayers, 1972).

This fraction accounts for relatively small amounts of $\mathrm{Fe}$ and $\mathrm{Cr}$, with values ranging from $2-35 \%$ of the N-L metals (see Table III). About a third of the N-L Cu, almost half of the N-L Zn, and up to $75 \%$ of the N-L Mn are in this fraction. Except for $\mathrm{Zn}$, all metals in the carbonate and exchangeable fraction reflect the distribution of detrital calcite and dolomite in the bay, with the highest heavy-metal concentrations in the carbonate-rich eastern portions of the bay, suggesting a detrital origin for these metals.

As discussed above, the concentration increase of heavy metals with decreasing grain size may be due to differential aeolian weathering of the various detrital components. Also, the proportions of these components in a sediment will vary depending on such physical factors as proximity to different sources. Therefore, one cannot compare the concentrations of metals from the various sediment and coastal bluff samples without normalizing in some way. We have normalized these concentrations by calculating the weight of sediment dissolved in a given extraction and expressing the concentration of metal dissolved in the same extraction as a fraction of that dissolved sediment weight, rather than the total sediment weight. The normalized metal concentrations for sediment and coastal samples are listed in Table IV. They are divided by average grain size into "muddy" and "sandy" samples to allow better comparisons. The table indicates that the concentrations of all elements except $\mathrm{Zn}$ are less than 10 times higher in the carbonate-exchangeable fraction of the sediments than in the bluff samples. This could be indicative of a detrital source for these metals, with possible preferential dissolution of the Ca over the heavy-metal carbonates.

On the other hand, normalized concentrations of $\mathrm{Zn}$ in the bay sediments show large variability and average almost 70 times the $\mathrm{Zn}$ concentrations in the outcrop carbonates (Table IV). The high concentrations of carbonateexchangeable $\mathrm{Zn}$ found here agree with the results of Nussmann (1965) for Lake Superior. He suggested that $\mathrm{Zn}$, perhaps from pollution sources, entered the sediment as absorbed ions or carbonate species. The waters and sediments of southern Lake Michigan also show high $\mathrm{Zn}$ concentrations (Shimp et al., 
1971; Copeland and Ayers, 1972; Leland and Shimp, 1973), with surficial sediment concentrations consistently higher than those at depth. In the present study, $\mathrm{Zn}$ was the only metal with dissolved concentrations high enough to be detectable in the water-soluble fraction (up to $25 \mathrm{ppm}$ ). Leland and Shimp (1973) suggest that the high concentrations of $\mathrm{Zn}$ are due primarily to atmospheric input from the industrial area bordering Lake Michigan on the southwest. Cline and Chambers (1977), however, found some evidence for upward migration of $\mathrm{Zn}$ in cores from eastern Lake Michigan. Based on all evidence, it is likely that both factors, i.e. upward migration and pollution input (from a distant source), are contributing to high surficial $\mathrm{Zn}$ concentrations.

\section{Organic and sulfide fraction}

Heavy metals become associated with organic matter through biological uptake, and adsorption with subsequent incorporation into resistant organic degradation products, such as humic substances. Metal sulfides can be either detrital or formed as a result of diagenetic processes in reducing layers of sediments. In Little Traverse Bay, organics are probably the major source of metals in this extraction because all metals which have high concentrations in this fraction also show high correlations with organic content throughout the bay.

Of the metals studied, $\mathrm{Cr}$ has the highest relative amounts in this fraction, averaging $43 \%$ of the N-L Cr (Table III). The $\mathrm{Cr}$ is probably in the +3 oxidaoxidation state, which is readily complexed with organics or sorbed in hydrous form onto sediment particles. These complexes are relatively inert and thermodynamically metastable forms can exist for long periods of time (Cotton and Wilkinson, 1972).

Like $\mathrm{Cr}, \mathrm{Cu}$ is heavily concentrated in this fraction which accounts for an average of $41 \%$ of the $\mathrm{N}-\mathrm{L} \mathrm{Cu}$. Other researchers, including Shimp et al. (1971), Copeland and Ayers (1972), Fitchko and Hutchinson (1975) and Cline and Chambers (1977) have found elevated concentrations of $\mathrm{Cu}$ in Great Lakes waters and/or surficial sediments due to pollution input from rivers and have suggested $\mathrm{Cu}$-organic complexes as the major form of $\mathrm{Cu}$.

The percentage of N-L Fe in this fraction is variable, ranging from 9 to $68 \%$ (Table III). This variability probably results from competition between Fe-organic complexes and hydrous Fe-oxide forms. This situation is complicated because hydrous Fe oxides themselves can complex with organics, especially humic substances, in sediments (Greenland, 1971). Thus the differentiation between inorganic and organic Fe species is not always definitive in natural aquatic systems.

As discussed in the previous section, sediment $\mathrm{Zn}$ has high normalized concentrations in every phase compared with bluff values. About one-third of the N-L $\mathrm{Zn}$ is in the organic-sulfide fraction. In general, the normalized sediment concentrations of all metals in this phase fall in between the high 


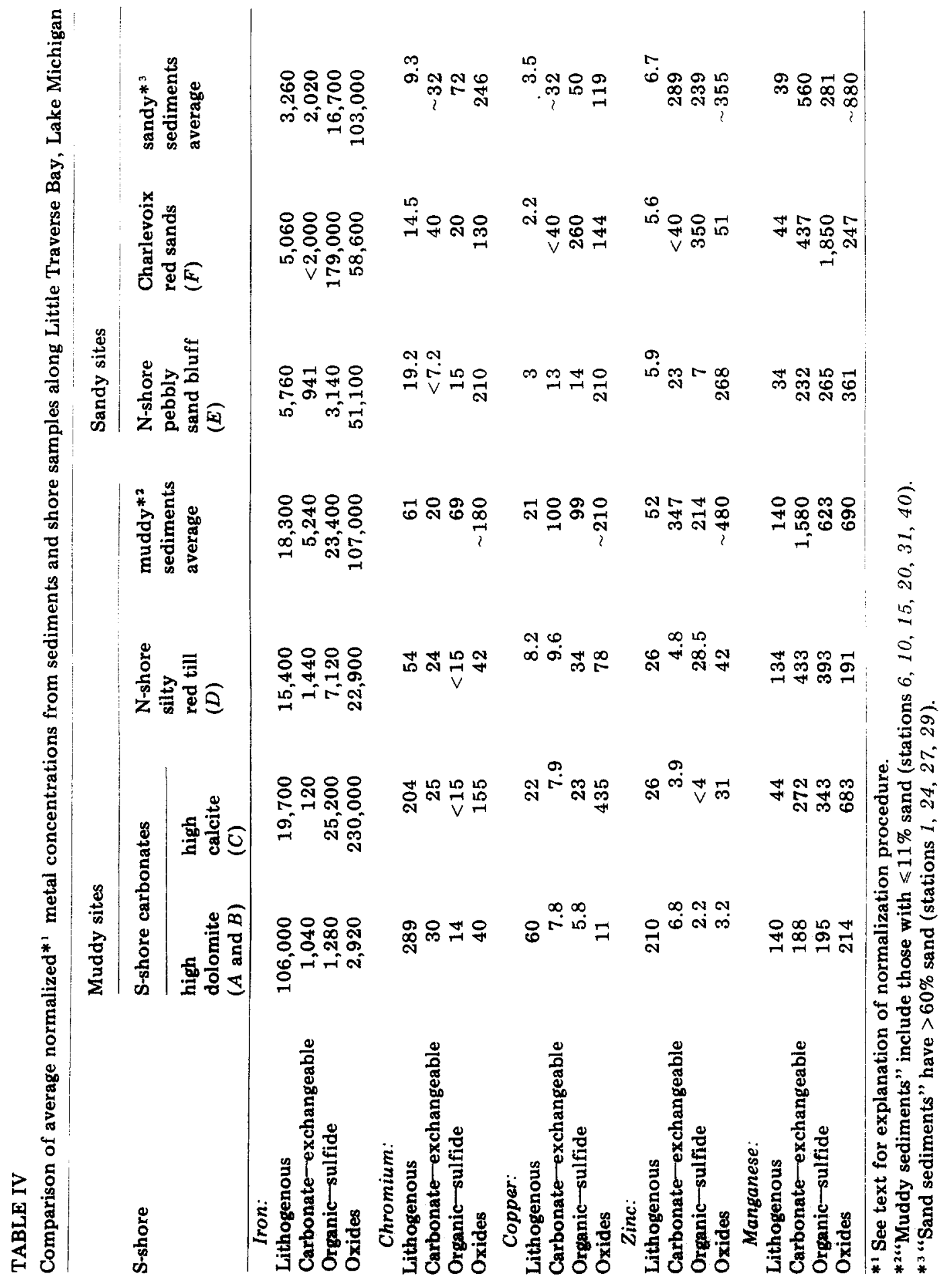


values of beach sands along the coast southwest of the bay and the much lower bluff concentrations along the bay proper (Table IV). This suggests that much of the organic input of heavy metals may be from sources outside the bay.

Easily reducible $\mathrm{Mn}$ oxides were removed in this extraction and the Mn listed in Table III for this fraction includes not only organics and sulfides, but also acid-soluble $\mathrm{Mn}$ oxides. In spite of the variety of phases represented by this fraction, only about one-quarter of the N-L Mn is present here, except for station 24, which contained Mn nodules.

\section{Moderately reducible fraction}

Heavy metals can associate with hydrous Fe oxides either by coprecipitation or by sorption onto pre-existing oxide coatings. These processes are very sensitive to changes in redox potential, and minor station-to-station variations may greatly affect the relative amounts within this fraction. The interrelation between the Fe oxides and organics as discussed above also complicates the distribution patterns.

Most of the N-L Fe (30-80\%) in Little Traverse Bay is in the form of hydrous oxides. The muddy stations contain the highest actual concentrations, while the sandy stations have the highest relative percent. Within the muddy stations, this fraction generally decreases in dominance from east to west. At station 24, the western-most station and only one at which Mnnodules were found, the concentration of $\mathrm{Fe}$ in the reducible fraction is low, suggesting an antipathetic relationship between the $\mathrm{Fe}$ and $\mathrm{Mn}$ oxides.

Of the remaining metals, $\mathrm{Cr}$ has the highest percentages in this fraction (averaging $38 \%$ of the $\mathrm{N}-\mathrm{L}$ metal), while $\mathrm{Cu}$ and $\mathrm{Zn}$ show a moderate affinity for the oxides (averaging 24 and 21\%, respectively). At station 24, which contained Mn-rich nodules, only small amounts of these metals were recovered.

\section{CONCLUSIONS}

The distribution of heavy metals among various geochemical fractions in sediments depends upon several factors, including source materials, weathering processes, sediment transport, and dissolution and redox reaction kinetics. In Little Traverse Bay, the physical factors are of primary importance for $\mathrm{Fe}$, $\mathrm{Cr}$ and $\mathrm{Cu}$, whereas authigenic processes control the more mobile $\mathrm{Zn}$ and $\mathrm{Mn}$, especially in areas of nodule formation.

These conclusions are based on three lines of evidence: (1) increased concentrations of non-lithogenous metals (i.e. those metals not actually incorporated into the lattice structure of crystalline minerals) in fine grain sizes are not commensurate with the increased surface area of these grains; (2) distributions of metals in the most mobile phases (i.e. carbonates and exchangeable metals) reflect the distribution of detrital carbonate input for all 
metals except $\mathrm{Zn}$; and (3) normalized concentrations of all metals except $\mathrm{Zn}$ reflect the concentrations and chemical partitioning of bordering bluff and outcrop samples.

The individual metals show distinct trends: $\mathrm{Fe}$ and $\mathrm{Cr}$ are concentrated mainly in the crystalline fraction, while among the non-lithogenous fractions, these metals are concentrated mainly in the oxide and organic phases; $\mathrm{Cu}$ and $\mathrm{Zn}$ are fairly evenly distributed among all fractions, with the organic fraction showing slight dominance for $\mathrm{Cu}$ and the carbonate-exchangeable fraction for $\mathrm{Zn}$. Mn exists mainly as a detrital carbonate or amorphous oxide within the bay and as micro-nodules in the outflow channel.

\section{ACKNOWLEDGEMENTS}

The work upon which this publication is based was supported in part by funds provided by the United States Department of the Interior, Office of Water Research and Technology as authorized under the Water Resources Research Act of 1964. Portions of this work were also supported by Grant No. 2189-77 from the Geological Society of America, and by Grants-in-Aid of Research from Sigma Xi and the Rackham Faculty Research Fund of The University of Michigan. We wish to express our thanks to D.K. Rea and J.D. Pigula for providing the sediment textural data, and to D.K. Rea for his critical reading of the manuscript.

\section{REFERENCES}

Chao, T.T., 1972. Selective dissolution of manganese oxides from soils and sediments with acidified hydroxylamine hydrochloride. Soil Sci. Soc. Am. Proc., 36: 764-768.

Chester, R. and Hughes, M.J., 1967. A chemical technique for the separation of ferromanganese minerals, carbonate minerals and adsorbed trace metals from pelagic sediments. Chem. Geol., 2: 249-262.

Cline, J.T. and Chambers, R.L., 1977. Spatial and temporal investigation of heavy metals in lake sediments near Sleeping Bear Point, Michigan. J. Sediment. Petrol., 47: 716727.

Copeland, R.A. and Ayers, J.C., 1972. Trace Element Distributions in Water, Sediment, Phytoplankton, Zooplankton, and Benthos of Lake Michigan: A Baseline Study with Calculations of Concern-Factors and Buildup of Radioisotopes in the Food Web. Environmental Research Group, Ann. Arbor, Mich., $271 \mathrm{pp}$.

Cotton, F.A. and Wilkinson, G., 1972. Advanced Inorganic Chemistry, 3rd ed. WileyInterscience, New York, N.Y., 1145 pp.

Engler, R.M., Brannon, J.M., Rose, J.R. and Bigham, G.N., 1974. A practical selective extraction procedure for sediment characterization. Symp. on Chemistry of Marine Sediments, Natl. Am. Chem. Soc. Meet., Atlantic City, N.J., 1974.

Filipek, L.H. and Owen, R.M., 1978. Analysis of heavy metal distributions among different mineralogical states in sediments. Can. J. Spectrosc., 23: 31-34.

Fitchko, J. and Hutchinson, T.C., 1975. A comparative study of heavy metal concentrations in river mouth sediments around the Great Lakes. J. Great Lakes Res, , 1: 46-78.

Folk, R.L., 1974. Petrology of Bedimentary Rocks. Hemphill, Austin, Texas, 182 pp.

Gibbs, R.J., 1973. Mechanisms of trace metal transport in rivers. Science, 180: 71-72. 
Gibbs, R.J., 1977. Transport phases of transition metals in the Amazon and Yukon Rivers. Geol. Soc. Am. Bull., 88: 829-843.

Greenland, D.J., 1971. Interactions between humic and fulvic acids and clays. Soil Sci., 111: $34-41$.

Gupta, S.K. and Chen, K.Y., 1975. Partitioning of trace metals in selective chemical fractions of nearshore sediments. Environ. Lett., 10: 129-158.

Leland, H.V. and Shimp, N.F., 1973. Factors affecting the distribution of lead and other trace elements in Southern Michigan. In: P.C. Singer (Editor), Trace Metals and MetalOrganic Interactions. Ann Arbor Science Publishers, Ann Arbor, Mich., pp. 88-129.

Moore, J.E., 1961. Petrography of northeastern Lake Michigan bottom sediments. J. Sediment Petrol., 31: 402-436.

Mothersill, J.S., 1977. Selected element concentrations in the post-glacial sediments to Thunder Bay, Lake Superior: distribution and methods of analysis. Can. J. Earth Sci., 14: 1054-1061.

Nissenbaum, A., 1972. Distribution of several metals in chemical fractions of a sediment core from the Sea of Okhotsk. Isr. J. Earth Sci., 21: 143-154.

Nussmann, D.G., 1965. Trace elements in the sediments of Lake Superior. Dissertation, University of Michigan, Ann Arbor, Mich. (unpublished).

Pigula, J.D., Rea, D.K. and Owen, R.M., 1977. Sediment types and their distribution in Little Traverse Bay, Lake Michigan. 40th Annu. Meet. Am. Soc. Limnol. Oceanogr., E. Lansing, Mich., 1977.

Rea, D.K. and Pigula, J.D., 1977. Sediment distribution and inferred transport processes in Little Traverse Bay, Lake Michigan. 20th Conf. on Great Lakes Research, Ann Arbor, Mich., 1977.

Stumm, W. and Morgan, J.J., 1970. Aquatic Chemistry. Wiley-Interscience, New York, N.Y., 583 pp.

Shimp, N.F., Schleicher, J.A., Ruch, R.R., Heck, D.B. and Leland, H.V., 1971. Trace element and organic carbon accumulation in the most recent sediments of southern Lake Michigan, III. U.S. Geol. Surv. Rep., Environ. Geol., Note No. 41, 25 pp.

Sly, P.B. and Thomas, R.L., 1974. Review of geological research as it relates to an understanding of Great Lakes limnology. J. Fish Res. Board Can., 31: 795-825. 